\title{
Service Management in Production Companies
}

\author{
Alexander Karapidis \\ Fraunhofer Institute Arbeitswirtschaft und Organisation, Nobelstrasse 12, D-70569 Stuttgart, \\ Germany. \\ Email: Alexander.Karapidis@iao.fhg.de
}

\begin{abstract}
Services are going to move in this decade to being the front edge of the industry" (Ante, Sager 2002, pp. 66-72).

In the past, with regard to product development production companies focused mainly on the intermediate product engineering process. In comparison, the service processes within the creation, modelling and marketing phase of the product development are less standardised. Moreover, the service shares in hybrid products are often hand-made styled and also less standardised. Service Management in production companies is focussing on customer expectations, service standards, service marketing and service communication. Especially the fit for service engineering approach helps to bring the service engineering process on a level of systematic standardisation comparable to the product engineering process. It gives answers how the partly "soft factors" driven service processes can be controlled by a strategic management approach. In this fit for service engineering approach the competence card is a key instrument. It helps to structure, measure and evaluate the service processes and gives organizational hints which skills should be improved for a better service engineering performance of production companies.
\end{abstract}

Key words: Service management, Service engineering

\section{PRODUCT ENGINEERING vS. SERVICE ENGINEERING - ARE TWO WORLDS COLLIDING?}

Product life-cycles are getting shorter, cost-value ratio is going down, products are getting increasingly complex - these are three among many rea- 
sons as an outcome of a highly competitive global market. Today, even complex products can be copied fast and from many companies world-wide. As an outcome of this development, unique selling points are much harder to find than in the past. The strategy to have intelligent and high effective and efficient processes in production engineering seems to be a key competence for companies to reduce the time-to-market, hidden costs and to offer highquality products (see MILLER, VOLLMANN 1985, pp. 142). So even in traditional production companies significant services are required to support the physical products.

To recognize the differences between a product and a service, we first look at a short definition of service:

"Services includes all economic activities of companies, whose output is not a physical product."

\begin{tabular}{|c|c|}
\hline 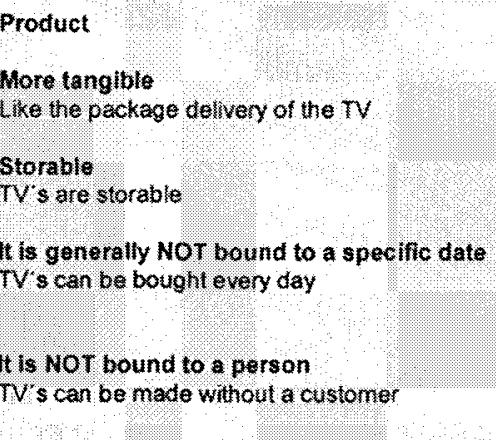 & $\begin{array}{l}\text { Service } \\
\text { More tangible } \\
\text { Like a TV } \\
\text { NOT storable } \\
\text { TV delivery is not storable } \\
\text { Generally consumed at the time it is produced } \\
\text { The package defivery is only consumed when the } \\
\text { TV is delivered } \\
\text { trs bound to a person } \\
\text { The package delivery can only be when there's a } \\
\text { customer who bought the TV }\end{array}$ \\
\hline
\end{tabular}

Figure 1. The differences between service and product

But it is much easier to understand, in comparing attributes of products and services (see figure 1). Some services are critical factors for success and most of them strengthen the value of the product (BRÄNNSTRÖM, ELFSTRÖM, THOMPSON 2001, p. 1). As a result, it is difficult to draw a distinction between products and services, since nearly all products include services which are vital for their value (NORMANN, RAMIREZ 1994). Physical products and services usually meet at two levels: In product development (e.g. construction, marketing, data processing) and in the support of physical products (e.g. hybrid products = computer and support for 2 years).

Thus it is not a scientific debate about physical products vs. services but a fact that the integration of physical products and services into service packages are used to increase the competitiveness (see BULLINGER, SCHEER 2003, pp. 26). The VDMA (the federation of the engineering industries) stresses that many companies carry a high yield from services and not from 
their products. Unfortunately, as a result of several studies the importance of services in production companies is still underrated (e.g. EGGERS, WALLMEIER, LAY 2000).

\section{Example: Pontiac LeMans GM \\ International production \& service parts measured by the car costs}

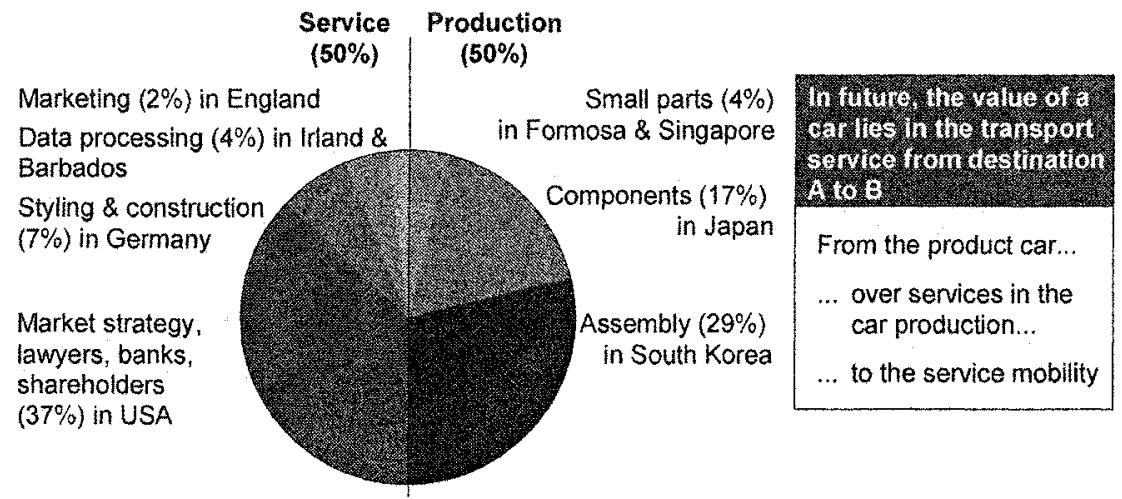

Figure 2. Service parts in car production

(REICH 1996)

Nevertheless, this assumption raises the question, why production companies have on the one hand well-developed tools and methods to design products but often have hand-made processes to design services on the other hand.

Various methods and procedures have been worked out and developed properly for physical products. Standardisation aspects underlie a worldwide permanent and continuous process. The measurement of product engineering processes is well worked-out. On the other hand, almost every production company has a large fraction of service parts, not only in administration, distribution or marketing departments, but also in core production areas.

Despite many approaches, it is very difficult to bring the "two worlds" production and service together. Especially hybrid product development and engineering stresses the difficulties when a high standardised and systematic product development meets hand-made styled product services. 


\section{SERVICE PERFORMANCE MANAGEMENT IN PRODUCTION COMPANIES}

In the last years, activities in service development in production companies have been dominated by marketing, quality management and customer relationship management. But these activities cover only some issues in improving the service performance of tourism companies.

ZEITHAML and BITNER (2003, pp. 31) stressed in their gap model of service quality four points which are the most important issues for service providers to avoid a low service performance:

- Gap 1: The management of a company does not know the expectation of their customers

There is a lack between the customer expectations and perceptions. Production companies should offer services that satisfy consumers' needs and expectations but also ensure their economic survival.

- Gap 2: The provision of services are configured inadequately

The expectations of clients are not satisfied, because of services not appropriate to customers' desires. This mismatch results from a shortage of standards in service design and standardized processes - especially in dealing with intangible assets.

- Gap 3: The information about services does not correspond with the effective achievement

There is a gap in connecting the service design with the actual service performance by company employees and the organisation of work. This brings companies to contradictory situations between customers' needs and employees' service provisions. As a result, employees often have to act beyond organisations rules to satisfy customers' needs with the effect, that high service quality is difficult to reproduce. Consequently, customers are not satisfied and employees permanently have to go beyond their capacity (NELSON 1970, p. 311; GROVE et al. 2001, p. 84).

- Gap 4: The assurance of the provisions of services does not correspond with the result

There has to be a fit between the external communication to customers and the service delivery of companies i.e. appropriate marketing communication especially with regard to cost-performance ratio concerns. 


\title{
Gaps of service quality
}

\author{
Gap in cognition (1) \\ The company does not know what \\ their customer expects \\ - Desiderative communication \\ - Deficient customer management \\ - Deficient market research
}

\author{
Gap in development (2) \\ The services do not have the right \\ service quality and standards \\ - Bad service design and -engineering \\ - Missing customer oriented standardisations and QM \\ - Inadequately configuration of the environment
}

\section{Service Performance Gap}

Gap in achievement (3)

the companies' service standards do not fit to the service performance by their employees

- Shortfalls in human resource management

- Bad coordiriation of supply and demand

- Shortfalls in customer behaviour
Gap in communication (4)

The services do not correspond with the effective achievement

- No cansistance marketing communication

Figure 3. Service Gap Model

For these reasons, most of the new service performance management methods and tools are focussing on the following points to bridge the gaps:

- The translation of visions and strategies in measurable factors of success seen by stakeholders and clients.

- The combination of key data for material and intangible assets.

- The provision of instruments to evaluate and improve the success of a company.

- The empowerment of managers and staff.

- The implementation of change in organizations.

The awareness that the success of services in production companies depends on the conceptual design and configuration is not very widespread. That implicates to see services as service products which have to be developed and managed like products as in e.g. the automotive industry. So, the question is to find methods, tools and instruments to close these gaps.

3.

\section{SERVICE ENGINEERING - CLOSING THE GAP BETWEEN STANDARDISED PRODUCTS AND HAND-MADE SERVICES}

One argument for not focussing on standardised and systematic service design is that the production companies are traditionally strongly focused on their products. So, the attitude of the management towards service development and engineering departments is weak or even non-existing. Another reason for neglecting standardisation lies in the lack of knowledge of service 
design concepts. However, HOLLINS and HOLLINS (1991), RAMASWAMY (1996) and BULLINGER and SCHRAINER (2001) have developed substantial applied concepts, studies and tools for professional service development. FÄHNRICH (1999, pp. 18) stressed that the transformation from traditional product development methods is unsuitable to develop services. Moreover, interdisciplinary methods are necessary which combine human resources, organisational aspects and technologies. In addition to that, a formal order for steps in the process of service development is represented by the service engineering concept applied by the Fraunhofer Institute for Industrial Engineering (IAO).

The aim of service engineering is to develop high quality customer-oriented services.

Advantages for production companies lie in (see MEIREN, BARTH 2002, p. 11):

- Competition advantages: Especially in turbulent markets innovative services are critical factors for success

- Building-up business segments: Service development as an operative link between customer needs and physical product development

- Success of the product in target markets: By respecting customer and market needs systematically in service development, the value of products raises

- Time-to-Market: By standardising service development processes time and costs for products decrease

- Knowledge Management: Product know-how and attributes can be better transferred between different development projects

- Customer Relationship Management: Some studies show that reasons why production companies lose clients mainly lie in problems with the service quality

- Transfer of service know-how: The service engineering concept lowers the barrier to transfer product-related services from one product to another

Some fields of application of the service engineering concept: FESTO AG \& Co., traditionally a production company which produced components for automation, successfully applies the service engineering concept for their customer logistics service (Kanban Service). Lufthansa AG sets up service engineering projects in innovative services for e-procurement. Schenker Germany AG (transport \& logistics) worked out customised services with the service engineering concept.

By using the service engineering concept the gap between production and service development has been closed. Product service innovation, service diversification and the development of product supporting services can be 
developed more professionally even if there are still open questions (see BULLINGER, MEIREN 2001, p. 163).

\section{Service Development Roadmap}

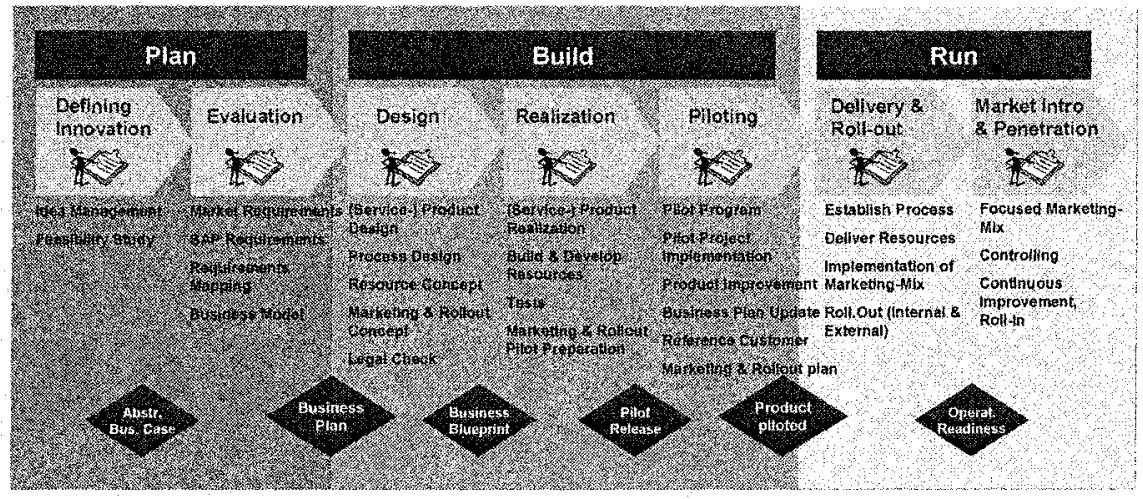

Figure 4. The service engineering concept

(Source: KARAPIDIS 2003, p. 325)

Exactly gap one and gap two are closed. The company does not know what the customers expect. So you need a standardisation and a professional market research. This is the first step en route to more service in production companies.

The second step includes closing gap two - the services do not have the right service quality \& standards. Right service quality and standards can be realised with a joint customer engineering.

\section{COMPETENCE CARD - MEASUREMENT AND MANAGEMENT OF SERVICE QUALITY AND SERVICE COMPETENCE}

Fit for service engineering in production companies also means to start improvement processes for services continuously. A precondition is to install a monitoring system for service quality and processes. Benchmarking is a method production companies are familiar with for a long period of time. Unfortunately, benchmarking concepts from production cannot be transferred one to one to services - in particular, when we need benchmarks for a strategic approach. In the last years, the Balanced Scorecard and the EFQMmodel broke the ice to include "soft factors" in the benchmarking topic (KAPLAN, NORTON 1997). The competence card used the strength of 
these concepts to allow a management and measurement for service quality and service competencies of companies (GANZ, TOMBEIL 2000).

Putting the competence card into practice means to structure strategies and to transfer these into action on production-related and service-related topics.

The work on the contents of a competence card which is specific to a particular field of growth is cascaded from one dimension to another in accordance with a uniform concept (see KARAPIDIS 2002, pp. 17).

Production-related topics will be measured on the control level. Organisational (service) competencies will be measured on the enabler level (see Figure 5) by ranking the status of the competencies on a stage model with qualitative degrees. Measures to develop and/or establish organisational competencies can be derived from the qualitative degrees which have not been reached yet. That means gap three is closed - the companies service standards do not fit to the service performance by their employees.

In combining these two measurement processes the decision security of companies rises (e.g. to improve production and service developments) and a human resource management can be improved, supplied and a demand coordination can be implanted in companies strategy.

\section{Measuring Service Performance}

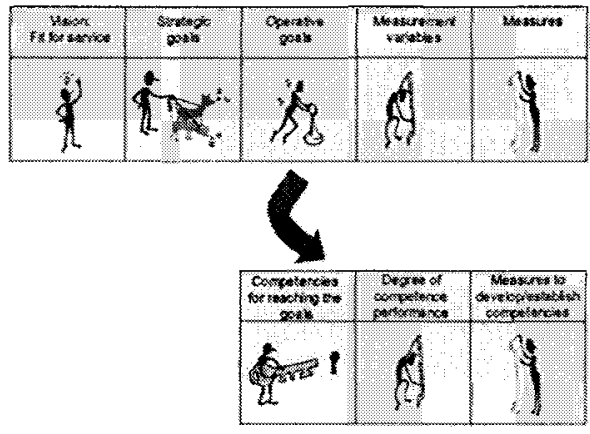

Control Level:

Structuring and balancing strategies from different perspectives and transferring these into action.

\section{Enabler Level:}

Structuring and balancing organisational competencies which are critical factors for success for an organisation in handling market-specific requirements.

Figure 5. The Competence Card

\section{SUMMARY AND FORECAST}

Service management in production companies means a paradigm shift from a customer's point of view: Yesterday, customers bought a product, today they buy a hybrid product to solve problems they have. From a pro- 
ducer's point of view, a production company firstly develops into a service production company which differs in services to the competitors. Its service offers are increasing and the company then yields a growing amount of money with services. Finally, service production companies will develop into "producing service companies" which offer customer-oriented hybrid solutions and integrated products. The service engineering concept and the competence card are the key methods to significantly increase the service quality and the service productivity of production companies as well.

Yesterday a customer bought a product, today they buy a solution that consists of different services around and within products.

\section{REFERENCES}

ANTE, S. E.; SAGER, I.:

IBM's New Boss".

In: Business Week,

New York, NY, 11 February 2002, pp. 66-72.

BRÄNNSTRÖM, O.; ELFSTRÖM, B.-O.; THOMPSON, G.:

Functional Products create new Demands on Product Development Organisations.

In: Design methods for performance and sustainability: 13th International Conference on

Engineering Design - ICED'2001.

Ed.: CULLEY, $S$.

Bury St. Edmunds et al.: Professional Engineering Publisher, 2001.

BULLINGER, H.-J.; MEIREN, T.:

Service Engineering - Entwicklung und Gestaltung von Dienstleistungen.

In: Handbuch Dienstleistungsmanagement.

Edts.: BRUHN, M.; MEFFERT, $H$.

Wiesbaden: Gabler Verlag, 2001, pp. 149-175.

BULLINGER, H.-J.; SCHEER, A.-W. (edts.):

Service Engineering: Entwicklung und Gestaltung innovativer Dienstleistungen.

Berlin, Heidelberg et al.: Springer Verlag, 2003.

EGGERS, T.; WALLMEIER, W.; LAY, G.:

Innovationen in der Produktion 1999. Dokumentation der Umfrage des Fraunhofer-

Instituts für Systemtechnik und Innovationsforschung.

Karlsruhe: Fraunhofer ISI, 2000.

FÄHNRICH, K.-P.; MEIREN, T.; BARTH, T.; HERTWECK, A.; BAUMEISTER, M.;

DEMUB, L.; GAISER, B.; ZERR, K.:

Service Engineering. Ergebnisse einer empirischen Studie zum Stand der

Dienstleistungsentwicklung in Deutschland.

Stuttgart: Fraunhofer IAO, 1999.

GANZ, W.; TOMBEIL, A. S.:

Von der Balanced Scorecard zur Competence Card als strategisches

Umsetzungsinstrument für Dienstleistungsbenchmarking.

In: Benchmarking 2000 in der Dienstleistungswirtschaft.

Edts.: MERTINS, K.; KOHL, H.; HEISIG, P.; VORBECK, J.

Berlin: Frauenhofer IPK, 2000. 
GROVE S. J.; Fisk R. P.:

Service theater: An analytical framework for service marketing.

In: Service marketing.

Ed.: Lovelock, C.

Englewood Cliffs: Prentice Hall, 2001.

HOLLINS, G.; HOLLINS, B.:

Total Design: managing the design process in the service sector.

London: Pitman Publishing, 1991.

KAPLAN R. S.; NORTON, D. P. (edts.):

Balanced Scorecard: Strategien erfolgreich umsetzen.

Stuttgart: Schäfer-Poeschel, 1997.

KARAPIDIS, A.:

Die Competence Card umsetzen - exemplarische Vorgehensweise aus zwei "Fit for Service"-Clubs.

In: Fit for Service Report 2002, Dienstleistungsbenchmarking (german report) - Service-

Benchmarking (english report).

Edts.: GANZ, W.; HOFMANN, J.

CD-Rom.

Stuttgart, 2002.

KARAPIDIS, Alexander:

Fit for Service Engineering in Production Companies.

In: Human Aspects in Production Management.

Eds.: ZÜLCH, Gert; STOWASSER, Sascha; JAGDEV, Harinder S.

Aachen: Shaker Verlag, 2003, pp. 322-329.

(esim - European Series in Industrial Management, Volume 5)

MEIREN, T.; BARTH, T.:

Service Engineering in Unternehmen umsetzen. Leitfaden für die Entwicklung von

Dienstleistungen.

Stuttgart: Frauenhofer-IRB-Verlag, 2002.

MILLER, J. G.; VOLLMANN, T. E.:

The hidden factory.

In: Harvard Business Review,

Boston, MA, 63(1985)5, pp. 142-150.

NELSON, P.:

Information and Customer Behaviour.

In: Journal of Political Economy,

Ort, 78(1970)20, pp. 311-329.

NORMANN, R.; RAMIREZ, R:

Designing Interactive Strategy. From Value Chain to Value Constellation.

Chichester et al.: Wiley, 1994.

RAMASWAMY, R::

Design and Management of Services Processes: keeping customers for life.

Reading, MA, Wokingham: Addison-Wesley, 1996.

REICH, R.:

Der US-Arbeitsmarkt: Erfolge und Herausforderungen.

In: Die Zukunft der Dienstleistung.

Edt.: MANGOLD, $\mathrm{K}$.

Frankfurt/M.: Frankfurter Allgemeine Zeitung, 1997, pp. 54-58. 
ZEITHAML, V.A.; BITNER M. J.:

Service Marketing. Integration customer focus across the firm.

New York, NY: McGraw-Hill, 2003. 